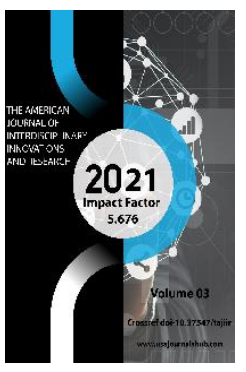

Journal Website: https://theamericanjou rnals.com/index.php/ta jiir

Copyright: Original content from this work may be used under the terms of the creative commons attributes 4.0 licence.

\section{Legal Aspects Of Implementation Of The Spouse's Inheritance Right}

\author{
Mamaraimova Gulrukh Makhmudovna \\ Senior Lecturer Of The Department Civil Procedural And Economic Procedural Law Of \\ Tashkent State Law University, Uzbekistan \\ Atalykova Guljazira Shurakhanovna \\ Teacher Of The Department Civil And Civil Procedural Law Of North-Kazakhstan State \\ University Named After M.Auezova, PhD, Uzbekistan
}

\title{
ABSTRACT
}

This article analyses the problems and solutions regarding the inheritance rights of the surviving spouse, whose legal marriage with the testator was not annulled, but who did not live together for many years before the termination of the actual family relationship, or who actually started a family relationship with another person. You can also familiarize yourself with the content of the legislation of Germany, France and Georgia on this issue.

\section{KEYWORDS}

Spouses, inheritance, opening of inheritance, first line of heirs by law, will.

\section{INTRODUCTION}

In accordance with the legislation of the Republic of Uzbekistan on succession, the inheritance is inherited on the basis of a will and legal succession. Inheritance by will is the first priority, because in it a person determines to whom his property and other rights and obligations will remain after the death of his will. In the case of legal inheritance, non- testamentary destiny arises when the testament does not fully cover the content of the inheritance, when the testament is declared invalid, when the testator (s) refuses to accept the inheritance or is declared an unworthy heir. 
Inheritance by law is a legal relationship ${ }^{1}$ and inheritance based on dependency factors, the wife (husband) who survived the death of the husband (wife) in the legislation of the Republic of Uzbekistan on inheritance is the first heir by law in relation to the inheritance of the deceased [1]. Current laws today raise the following issues in terms of the right of a husband or wife to inherit.

First, one of the most common cases is that a couple does not live together for many years without a legal marriage, and the fact that the surviving party is considered the heir to the inheritance of the deceased party often leads to objections. In a related civil case, the couple did not live together for twenty years without a legal divorce, and after the death of their husbands, their wives were also called upon to inherit as one of their first legal heirs. In practice, the absence of a marital relationship does not affect the rights of the husband or wife as heirs under current law at all.

We will look at how this situation is addressed in the legislation of other countries. In particular, Article 1933 of the German Civil Code sets out the grounds for excluding a couple's right to inherit. According to him, if the conditions for divorce were met at the time of the testator's death, and the deceased filed an application or consent for divorce, the living husband or wife is excluded from the right to inherit. This rule also applies if the testator has the right to declare the marriage invalid and to file it. [2]. It is clear from German law that in fact there are cases that exclude the right of the couple to inherit, and in order to better understand these, we also have to analyze the German legislation on divorce. Of the German Civil Code

Pursuant to Article 1564, a marriage may be divorced by a court decision at the request of both or one of the spouses. According to the analysis of Articles 1564-1568 of the German Civil Code on divorce, divorce is allowed at the request of one of the spouses if they have not lived together for at least one year and both spouses have filed for divorce or the other has consented if one of them applies is placed. Also, if the couple has not lived together for at least three years, the marriage may be considered broken. That may be the basis for a divorce.

If the couple has lived separately for less than a year, this is allowed if the continuation of the marriage is unbearably cruel to the applicant for reasons related to the identity of the other party. The content of German divorce norms considers that the couple's separate living is one of the important factors for divorce.

The conclusion is that if a husband and wife who have not lived together for at least one year have filed for divorce, or if one of them has filed for divorce and the other has consented and one of them has died during this period, the surviving husband or wife will receive a share of the deceased loses the right. Hudud also loses the right to inherit the other surviving party in the event of the death of the husband or wife who applied to the court in those circumstances, if there are grounds to declare the marriage invalid.

\footnotetext{
${ }^{1}$ According to the law, the adoptee and his descendants are equated, on the one hand, with the adopter and his relatives, on the other hand, with the birth relatives.
} 
Article 1341 of the Civil Code of Georgia provides for deprivation of inheritance after the death of a spouse who did not actually live together before the opening of the inheritance. That is, at least three years before the opening of the inheritance, if it is confirmed that the marriage was actually dissolved and the couple lived separately, the other party may be deprived of the right to inherit by law in accordance with the court decision. [3].

Also in the French Civil Code [ []] the issue of deprivation of the inheritance of a surviving spouse who has practically terminated the family relationship with the testator and lived separately shall be considered by the court.

As far as Italian law is concerned, the second book of the Italian Civil Code - Articles 581-585 of the Book of Inheritance - contains provisions on the right of a couple to inherit and the circumstances that exclude inheritance. In particular, under Article 585 of the Italian Civil Code, the conduct of a couple leading to a divorce may preclude the inheritance of a share.[7]

It is a bit difficult to provide accurate statistics on the number of cases in which a couple's legal marriage has not been annulled even though they have not lived together for many years. This requires a nationwide survey. However, there are statistics on cases of divorce after not living together for many years. In particular, the Agency for Public Services under the Ministry of Justice of the Republic of Uzbekistan in 2017 studied the reasons for the rulings. In 2017, there were 8,011 divorces registered by the FXDYO authorities at the joint application of the couple, of which 133 cases (1.6\%) were due to the couple not living together for a long time. In addition, in 2017, the courts granted 23,919 divorce applications. In 695 court cases, the reason for the divorce was that the couple had not lived together for a long time. [10, 11, 16].

In 2019, the Center for Family Research under the Cabinet of Ministers of the Republic of Uzbekistan conducted a survey of judges of civil courts operating in the country. The survey looked at the reasons for the divorces in their divorce cases

In $1.8 \%$ of cases, divorce was based on the fact that the couple did not live together for a long time.

These figures show that in practice there are cases when a couple does not live together for a long time without annulment of a legal marriage. In practice, it is necessary to reconsider the issue of succession of a couple who have actually terminated the family relationship.

Second, we also see many cases where a husband and wife have started a different marital relationship in practice without having their legal marriage annulled. It is more difficult to get real and complete statistics on this, which requires a nationwide survey.

However, we try to make effective use of available statistics. In particular, 31,930 divorces were registered in the country in 2017 , of which 1,629 were due to the fact that one or both spouses were actually married to another person. [8, 9, 12, 16] In 2019, $2.6 \%$ of the applications satisfied by the courts in divorce cases were cited as the reason why both or one of the spouses entered into a de facto family relationship with another person after a sharia 
marriage. This means that it is not uncommon for a couple to start a family relationship with another person without divorcing them legally. In this case, in practice, the family relationship is considered over. In practice, individuals whose family relationships have ended are considered heirs to each other because of the existence of an actual marriage. We believe that we need to reconsider these norms in our legislation. If we look at the legislation of other countries in this regard, especially in Germany, the fact that a couple has entered into a de facto marital relationship with another person gives the other person the right to file for divorce, and if he has filed such an application but still dies without a divorce case, the court in another practice, the party initiating the family relationship may be deprived of the share of the inheritance [2].

In this regard, we propose to include in the Civil Code of the Republic of Uzbekistan a rule to exclude the right of the couple to inherit. Currently, a new draft of this code is being prepared, and it would be expedient if the proposed norm is included in the rules of succession of the inheritance department. According to Uzbek law, the husband or wife of the deceased is his first legal heir.

The content of the norm we propose: According to the court decision, a surviving spouse who has effectively terminated the family relationship may be found to have lost the right to inherit by law in respect of the inheritance of the deceased spouse:

Has not practically lived together as a farm for at least three consecutive years prior to the opening of the inheritance;
Has not actually lived together on the same farm and has actually started living on the same farm with another person.

Based on the above, it can be concluded that a surviving spouse whose legal marriage with the testator has not been annulled, but who did not live together for many years before the actual termination of the family relationship, or who has actually started a family relationship with another person, is deprived of the right to inherit. and the prevention of legitimate objections in practice that arise when a spouse who has in practice terminated a family relationship and subsequently died is called as heir to the inheritance.

\section{REFERENCES}

1. Article 1135 of the Civil Code of the Republic of Uzbekistan. // Bulletin of the Oliy Majlis of the Republic of Uzbekistan, 1996, No. 11-12, Article 1;

2. Bürgerliches Gesetzbuch (BGB) // http://www.gesetze-iminternet.de/bgb/index.html.;

3. Civil Code of Georgia // https://matsne.gov.ge/ru/document/d ownload/31702/75/ru/pdf .;

4. Civil Code of Franch // http://www.fd.ulisboa.pt/wpcontent/uploads/2014/12/Codigo-CivilFrances-French-Civil-Code-englishversion.pdf.;

5. Emery, Robert E. (2013). Cultural Sociology of Divorce. An Encyclopedia. Thousand Oaks, Calif.: SAGE Reference. p. 416. ISBN 978-1412999588.;

6. https://www.gov.uk/divorce/groundsfor-divorce.; 
7. Italian Codice Civile 2020, Dispositivo dell'art.

$$
584
$$

https://www.brocardi.it/codicecivile/libro-secondo/titolo-ii/capoii/art584.html.

8. Мамараимова Г. М. Проблемы
наследования прав доменных имен по законодательству Республики Узбекистан //Журнал правовых исследований. - 2020. - Т. 5. - №. 2.

9. Мамараимова Гулрух ПРАВОВЫЕ ПРОБЛЕМЫ ТРАНСГРАНИЧНОГО НАСЛЕДОВАНИЯ

ИНТЕЛЛЕКТУАЛЬНОЙ

СОБСТВЕННОСТИ // Review of law sciences. 2020. №Спецвыпуск. URL: https://cyberleninka.ru/article/n/pravo vye-problemy-transgranichnogonasledovaniya-intellektualnoysobstvennosti (дата обращения: 27.07.2021).

10. Мамараимова Гулрух ПРАВОВЫЕ ПРОБЛЕМЫ ТРАНСГРАНИЧНОГО НАСЛЕДОВАНИЯ

ИНТЕЛЛЕКТУАЛЬНОЙ СОБСТВЕННОСТИ // Review of law sciences. 2020. №Спецвыпуск.

11. Mamaraimova G. INHERITANCE ISSUES OF NON-PROPERTY (MORAL) RIGHTS OF INTELLECTUAL PROPERTY // Norwegian Journal of Development of the International Science. 2021. №65-1. URL:

https://cyberleninka.ru/article/n/inherit ance-issues-of-non-property-moral-

rights-of-intellectual-property (дата обращения: 27.07.2021).

12. Mamaraimova G. INHERITANCE ISSUES OF NON-PROPERTY (MORAL) RIGHTS OF INTELLECTUAL PROPERTY //
Norwegian Journal of Development of the International Science. 2021. №65-1.

13. "No Fault Divorce Law \& Legal Definition". US Legal. Retrieved 3 June 2013.;

14. Statistics Kun.uz website (https://kun.uz/news/2018/12/12/ oilavijajrimlar-kalavaing-uci-kimin-kulida), Darakchi newspaper.

15. "The Meaning of Uncontested Divorce". SplitSimple.com. Retrieved 2017-01-14;

16. X.Nasimov, G.Mamaraimova. Marriage: a national and foreign experience. Information-analytical material. Tashkent, 2019. -B. 8-11 .;

17. 日本の民法 // http://www.moj.go.jp/content/000056 024.pdf. 